\title{
Cyberspace and gay rights in a digital China: Queer documentary filmmaking under state censorship
}

\author{
Gareth Shaw \\ and \\ Xiaoling Zhang \\ Correspondence Address: $\quad$ Gareth Shaw, School of Sociology and Social Policy, \\ University of Nottingham, University Park, Nottingham NG7 2RD \\ Gareth.Shaw@nottingham.ac.uk
}

\begin{abstract}
Owing to China's austere censorship regulations on film media, directors of films and documentaries engaging with lesbian, gay, bisexual and transgender themes have struggled to bring their work to domestic attention. Working outside of the state-funded Chinese film industry has become necessary for these directors to commit their narratives to film, but without approval of China's State Administration of Press, Publication, Radio, Film and Television, these artists have had little chance of achieving widespread domestic distribution of their work. However, advancements in new media technology and Web 2.0, ranging from digital video formats to Internet-based distribution via social media networks and video-hosting platforms, provide opportunities for Chinese audiences to access films and documentaries dealing with LGBT themes. This empirical study assesses how production, promotion and consumption of queer documentary films are influenced by the development of social media within Chinese cyberspace. Through close readings of microblogs from Sina Weibo this study combines analysis of contemporary research with digital social rights activism to illustrate contemporary discourse regarding film-based LGBT representation in China. Finally, the study comments on the role that documentary filmmaking plays in China's gay rights movement, and discusses the rewards (and challenges) associated with increased levels of visibility within society.
\end{abstract}

Keywords: cyberspace, LGBTQ, gay rights movement, film, documentary, censorship, microblog

In post-socialist China, independently-made documentary films have come to represent a grassroots form of social activism, highlighting instances of civil rights violations and corruption within contemporary China, along with serving to document (and challenge) prevailing attitudes towards a variety of social phenomena. In this respect, such documentaries have much in keeping with worldwide documentary films which seek to empower marginalized communities, ${ }^{1}$ and represent what Chris Berry has termed a 'socially engaged' mode of independent documentary film and video making, ${ }^{2}$ which stands as an instance of 'historically and socially specific transnational project'. ${ }^{3}$ Despite the important role played by such documentaries in community-building and social activism around the globe, ${ }^{4}$ China's regulatory framework provides formidable barriers to their production and distribution, as all forms of free expression that might be perceived to disrupt social harmony or challenge the political hegemony of China's ruling party are actively discouraged. It is therefore not surprising that, although research has demonstrated a gradual change in attitudes towards homosexuality within some sectors of contemporary Chinese society, ${ }^{5}$ the representation of queer lives on film is still fraught with obstacles. Film-based expression remains under fierce political scrutiny, ${ }^{6}$ and is subject to censorship, with guidelines from the State Administration of Press, Publication, Radio, Film and Television of the People's Republic of China (SAPPRFT 国家广播电影电视总局) ${ }^{7}$ requiring censorship of materials dealing explicitly with homosexuality owing to broad interpretation of obscenity legislation. ${ }^{8}$ 
Consequently, despite being considered as part of the wave of socially engaged media that has swept China in the wake of the emergence of digital video, ${ }^{9}$ contemporary queer documentaries operate in a grey area, without access to the more traditional televisual channels of distribution.

Following its introduction in 1998, the relative affordability (and portability) of digital video (DV) equipment has led to interest in a broad spectrum of the population. ${ }^{10}$ Such amateur documentary making has found a home on China's numerous digital media sharing platforms, representing what Chris Berry and Lisa Rofel have termed 'a wholesale transformation of public culture'. ${ }^{11}$ Accordingly, these documentary films represent a form of audio-visual production that is unrelated to film studios or TV production companies. ${ }^{12}$ More recently, the advent of camera-equipped smartphones and massive distribution opportunities via social networking sites has increased communicative capacity exponentially. Although such channels are not immune from the censorship that pervades more traditional media carriers, microblogging (known in China as 微博 weibo) has come to represent a convergence of official and non-official discourse, whereby China's authorities can engage in public opinion guidance and respond to public concerns. Thus, Chinese netizens are afforded opportunities for discussion on social and political issues that are otherwise denied to other forms of media. At the same time, distribution and consumption of video via online streaming sites is becoming increasingly popular, and offers potential for makers of lesbian- and gay-themed films to increase the visibility of their works to a domestic audience.

This paper focuses on the ways in which makers of documentaries dealing with homosexuality use new communication technology as a tool of promotion and distribution within China's censored visual media landscape. Previous studies have demonstrated influence of technology on the production, consumption and distribution of queer media in America, Europe and certain Asian locales, ${ }^{13}$ and studies engaging with the Chinese context are emerging. ${ }^{14}$ By answering the following research questions through literature review, the analysis of microblogs, online interviews with filmmakers, and an assessment of consumers' responses, this paper offers a more nuanced understanding of how newlyemerging tactics of artistic production and consumption works in China. In addition, it furthers scholarly investigation on the relationship between new communication technologies and queer films in the Chinese context. It also contributes to the greater discussion of Internet use in China, particularly regarding the implications of subverting the official political discourse of China's ruling party:

1. How are directors of tongzhi (同志 $)^{15}$ documentaries able to produce, promote and distribute their works within a regulated environment?

2. How are tongzhi documentaries consumed in China? What spaces - physical or otherwise - have been (re)claimed?

3. What effect does new media technology have on the creative process?

To answer the questions, the paper draws on the circuit of culture framework developed by cultural theorists in the late 1990s, ${ }^{16}$ which enables the authors to examine the whole process of how a cultural text or artefact is produced and consumed. It employs inter-disciplinary approaches including content analysis for the examination of online content, interviews with filmmakers and evaluation of consumers' responses. Data for the analysis comes from three sources:

1. For the examination of discourses on Chinese-language films, documentaries or other forms of visual media that feature the representation of tongzhi lives and relationships, microblog entries are collected and analysed from Sina Weibo, China's biggest microblogging platform which contains multiple open forums relating to the discussion of tongzhi matters. Data collection, using the names of directors Fan Popo (范坡坡) and Wei Xiaogang (魏建刚/魏小刚) ${ }^{17}$ search terms for their media and activism profiles in conjunction with the terms tongzhi (comrade/gay) and jilupian (纪录片) (documentary), spanned a period of 6 months beginning in January 2016 when the authors started 
the project. Online reaction and response is also examined.

2. To reveal the popularity of the online media, and also illustrate how the video is being promulgated in cyberspace, historical data from ten videos (see Figure 3) posted to Youku.com in 2012 are analysed. Youku's video diagnostics tools maintained records of referral traffic, whereby the URL of the video is linked to another website. This happens, for instance, if a netizen posts a link to the video in a blog, or on another website.

3. For assessment of how social networking is helping to promote their work (both domestically and abroad), and if new distribution methods are affecting the way in which their work is created and consumed, either interviews with renowned artists/filmmakers from previously published sources, or from email exchanges with Fan Popo for the purposes of this study, are conducted.

Wah-shan Chou uses the term lesbigay to refer to lesbians, bisexuals and gay people in the West, and tongzhi for contemporary Chinese lesbigay people. ${ }^{18}$ In this paper, we follow this distinction; however, queer is used in reference to academic or artistic discussion, and lesbigay is replaced with the more contemporary acronym of LGBTQ.

\section{Carving out a Space on the Digital Platform}

The representation of Chinese tongzhi in film and media within Mainland China represents an ongoing struggle between artistic expression and governmental censorship. Most films that can be interpreted as portraying same-sex attraction and relationships in a positive light are still banned in China. Many observers have commented that, as Internet technology has developed, so too have the regulations governing online visual media. Among other regulatory features, scholars have noticed and commented on the ambiguity of the guidelines, arguing that it is forcing self-censorship on practitioners. ${ }^{19}$ This lack of clarity with regard to prohibited content has been problematic for creators of digital content aimed at China's tongzhi community. Although homosexuality is not illegal in China, it receives no official approval (The authorities' stance is often cited as being one of 'no approval, no disapproval, no promotion' ${ }^{20}$ Loretta Ho has observed that the existence of dedicated tongzhi websites tend to be short-lived, owing in part to this regulatory ambiguity. ${ }^{21}$ Internet regulations in China are subject to frequent change. ${ }^{22}$ In addition to the 2010 guidelines on film censorship standards by SARFT (now SAPPRFT), further guidelines were released in 2016 regarding the provision of audio-visual programming. These regulations contained, amongst others, restrictions on materials that:

- Depict prostitution, fornication, rape and other ugly behaviours

- Express or display abnormal sexual relations or sexual behaviour, such as incest, homosexuality, perversion, sexual assault, sexual abuse, and sexual violence.

- Promote unhealthy views of marriage and relationships, including extra-marital affairs, one night stands, and sexual freedom. ${ }^{23}$

Makers of online queer documentary film content are continually testing the limits of public and official acceptability, but objection may not only come from official sources; notably, the makers of China's only online tongzhi webcast produced and aired a talk show-style discussion piece on lesbian sex toys, which was only removed from their website after one of the show's contributors complained about receiving harassment from members of the public. ${ }^{24}$

Furthermore, the availability of sources of financial assistance for makers of queer documentaries is very limited. Fan Popo, whose directing credits include 'Taipei: City of Rainbow' (台北: 彩虹之城; 2009), New Beijing, New Marriage' (新前门大街; 2011) and 'Be a Woman' (舞娘; 2011), lists financial resources as one of the main challenges facing queer documentary makers. ${ }^{25}$ As a result, more makers of independent films in China are turning to international sources of funding ${ }^{26}$ including Chinese queer documentary makers. Cui Zi'en's 'Queer China, “Comrade” China' (誌同志; 2008) Wei Xiaogang's 'Comrades, You've Worked Hard!' (同志们, 辛苦了; 2010) for instance, were both produced with assistance from the Ford Foundation. 
More recently, however, directors have moved away from traditional channels of filmmaking and distribution in favour of independent digital video productions as a way of bypassing censorship imposed on state-financed films. ${ }^{27}$ In addition to the shrinking cost of DV equipment, perhaps of greater impact still is the new generation of smartphones that have digital video recorders integrated into their camera facilities, pre-installed with software for shooting, editing and (crucially) sharing online videos with netizens around the globe. In such a digital environment, often the end consumer has, in turn, become a producer of content, as predicted by Marshall McLuhan and Barrington Nevitt, ${ }^{28}$ thus altering the landscape of the original medium through the formation of a new generation of prosumers. Accordingly, several of the short documentaries examined in this study, such as 'Me and Us', 'Approaching', and 'Because of Love', are the products of university students, who are representative of a new wave of educated, technology-enabled, curious young filmmakers, keen to explore social issues and engage public debate.

Many of China's established tongzhi filmmakers such as Fan Popo, Cui Zi'en and Wei Xiaogang combine activism and advocacy with their artistry, and as such have contributed towards both domestic and international academic discussion on Chinese tongzhi issues. ${ }^{29}$

\section{The website of Queer Comrades}

Queer Comrades is China's only independent and established LGBT webcast. ${ }^{30}$ As a provider of exclusively online content, Queer Comrades has embraced new media technologies as a way of connecting with China's tongzhi community. The production company maintains their own branded website, along with accounts held on Chinese social networking platforms Sina Blog and Sina Weibo, and on international sites such as Facebook and Youtube. Operating as a project under the Beijing Gender Health Education Institute, Queer Comrades works in partnership with the Ford Foundation. Beginning life as Queer As Folk Beijing, production started April 2007, eventually changing the name to Queer Comrades two years later, as the show entered its third season of online broadcasting. ${ }^{31}$ Over the past nine years, over 100 talk shows and documentaries have been uploaded to its video catalogue, covering a range of topics relating to the tongzhi community. Wei states that the creation process of Queer Comrades' videos, documentaries and news articles values substance over style, as 'We don't focus on being artistic and spend months editing. We're just a TV channel online for gay people'. ${ }^{32}$ Queer Comrades focuses on both domestic and global LGBT issues, and has a distinctly international feel to its on-screen presence. Although programming is delivered in Mandarin Chinese, Queer Comrades employs several hosts from European and American backgrounds. As is the case with many Chinese-made documentaries and films regarding tongzhi life and lifestyles, all of Queer Comrades' videos are provided with English subtitles, which enhances accessibility for international audiences.

\section{Connecting, engaging and reaching out}

With no recourse to state funding, and with the SAPPRFT restrictions barring cinematic depiction of homosexual relationships, traditional methods of promotion and distribution for makers of tongzhi films are not available. Although the content in this digital environment is also heavily regulated and monitored, the development of microblogging, a dominant carrier of social discourse within Chinese cyberspace, has revolutionized the face of the Internet around the globe, and users of Chinese cyberspace use microblogging as a tool for the promotion and distribution of tongzhi documentaries.

Figures provided by the China Internet Network Information Centre (hereafter as CNNIC) acknowledge that nearly $34 \%$ of China's 688 million netizens are actively engaged in microblogging through the Sina Weibo platform. ${ }^{33}$ Mobile Internet is highly utilized, with $90.1 \%$ of all Chinese netizens accessing the Internet via their mobile phones, ${ }^{34}$ facilitated by the recent roll-out of third- 
generation $(3 \mathrm{G})$ and fourth-generation $(4 \mathrm{G})$ networks..$^{35}$ This provides opportunities and challenges in equal measure to those who operate within the Chinese blogosphere, including those who use the Internet for the expression of sexual identity, all of whom must operate against a backdrop of political censorship and legal ambiguity.

A popular feature of microblogging is the ability of users to provide access (via hyperlinks) to other dynamic web-based content, usually on sites that provide digital music and video hosting. According to CNNIC, China's online video utilisation ratio had climbed to $73.2 \%$ at the end of $2015 .{ }^{36}$ This is important in the study of online queer documentary consumption, as it represents an effective method of distributing and promoting video clips from within the microblogging platform. Youku Toudo is one of China's leading Internet video providers of user-generated content, serving 450 million users per month as of $2014 .{ }^{37}$ Sites such as these have provided a platform for the production and consumption of spontaneous, free-flowing reporting on diverse social issues - contentious or otherwise - which have become a feature of China's New Documentary Film Movement. ${ }^{38}$

\section{Promoting tongzhi documentaries via Sina Weibo}

As a tool for marketing, the impact of international microblogging platforms such as Twitter is well documented. ${ }^{39}$ The Chinese market is not exceptional to this with regard to general commercial activity, and a cursory sweep of Sina Weibo reveals numerous instances of in-application targeted advertising. However, social networking sites are not only useful for the promotion of commercial activity, but are also vehicles for the distribution and promulgation of personal opinions. Users can thus unite to build online communities based around common interests and causes. Many of China's tongzhi NGOs and support groups use Sina Weibo as hub of communication; a way of reaching out to individuals, of co-ordinating activities and of raising the profile of the organisation. This gives tremendous scope for directors of queer films and documentaries to ally themselves with tongzhi NGOs and support groups in order to increase exposure for their work. In an environment of tight censorship, where directors have restricted opportunities for public display and distribution, Sina Weibo can serve as a way of increasing awareness and discussion of queer documentary making, and as a tool of promotion for screenings:

\section{FIG01}

Figure 1 shows evidence of discussion regarding Fan Popo's documentary film Papa Rainbow (彩虹 老爸; 2016). The entry has been reblogged 759 times (as of August 2016). The microblog format on Sina Weibo allows for each post to contain an accompanying image thumbnail, which can be either a still photograph or a small moving image file. Posts discussing tongzhi events frequently contain a copy of an advertising flyer or poster (as contained in the above microblog entry, indicated by the small image icon at the end of the text). These images can be easily expanded without leaving the newsfeed.

Figure 2 shows an original post by user @ 苏州LESGO公益小组 dated 29 June 2016 containing photos from a recent screening of the film. The microblog contains several @ mentions, ${ }^{40}$ which indicates onward distribution within the microblogging platform (in the example, @范坡坡就地掩埋王勇平 is the Weibo username of Fan Popo, so this post will also appear on his microblog page).

\section{FIG02}

Figure 3 demonstrates the promotion of queer video making tuition by Queer Comrades at speciallyrun workshops in Beijing, as part of its annual Queer University initiative:

\section{FIG03}

Community enhancement has been cited as filmmakers' motivation for creating their documentaries. ${ }^{41}$ 
The microblog posts illustrated here offer strong evidence to prove that microblogging is being used as a platform for the promotion and distribution of queer documentaries. However, most significantly, it is not only the directors who are engaging in promotion; users are sharing and discussing works that they consider to be of significance to the wider tongzhi community. In doing so, they are not specifically distributing documentaries in a physical sense, but rather are distributing their reputation, thereby affirming their existence and drawing attention to their position in the greater online and offline discourse.

Despite restrictions placed on freedom of speech within Chinese cyberspace, it is clear that the Internet provides a vital form of connection for Chinese tongzhi. Groups associated with the advancement of tongzhi civil rights have embraced Internet technology to create a networked discourse platform, which enhances public visibility and works towards challenging public perception of sexual diversity:

Nowadays, most of our events, videos and articles could be transmitted through Internet, especially via some web 2.0 applications such as Weibo. The new generation of the media is changing the way people think and live. The queer movement shouldn't be an exception. ${ }^{42}$

Makers of queer documentaries have recognized this development, and have begun to take advantage of new opportunities that the Internet is providing.

Microblogging sites and personal blogs have been used in China to promote awareness of film festivals, and provide a new way for both filmmaker and audience to interact. The following microblog posts taken from Sina Weibo are illustrative of how tongzhi interest groups are using microblogging as a form of advertising

\section{FIG04}

The latter of these two microblogs (which was @ mentioned on the Sina Weibo page of director Fan Popo) is of particular significance, as it demonstrates how microblogging is being used to engage in direct discussion with tongzhi directors and artists, and to alert festival organizers to increases in demand for the provision of queer documentary/film screenings.

To summarize, using microblogging as a tool for the discussion of queer subjects gives the topic far greater exposure than can be attained through niche websites aimed at tongzhi netizens. It can also be argued that a platform like Sina Weibo offers a more stable platform for such discussion, as the broad discussion medium operates with less risk of being shut down through regulatory ambiguity than the risk posed to dedicated tongzhi websites. ${ }^{43}$ That is not to say, however, that Sina Weibo offers a freefor-all on all areas of public discourse; Sina Weibo allegedly employs over 700 people to monitor microblog content ${ }^{44}$ and certain topics are often officially harmonized ${ }^{45}$ in response to inflammatory offline events that could be seen to undermine public security and trigger social unrest. However, many tongzhi microblogs still manage to carry links to officially banned tongzhi movies and documentaries. More confrontational still, some microbloggers even accompany their posts with images of a semipornographic nature, in direct contravention of Article 5 (Chapter 1) of the Computer Information Network and Internet Security, Protection, and Management Regulations. ${ }^{46}$

\section{From Offline to Online: Referrals, Exposure and Interconnectivity}

For a filmmaker, connecting with an audience is a vital end result of their labour. This section examines the public (and private) spaces that have been claimed by artists upon which to stage their work. The examination will assess evidence of the contributory role that new media technology is playing, specifically the Internet and associated social networking sites, on the consumption of queer visual media in China. 


\section{Beyond film festivals: alternative tactics for screening queer documentaries}

The public screening of independent films in China has been met with varied levels of resistance from the authorities. Homosexuality is not illegal in China, but public event gatherings still cause concern for the authorities. Discussing this issue, Bin Xu, director of Common Language, a lesbian, gay and transgender support group based in Beijing, claims that 'if something's different and you publicly promote it, they [the authorities] worry it could get out of control and threaten their harmonious society ${ }^{47}$ Chinese independent film festivals often therefore operate without official authority and without adhering to the SAPPRFT guidelines on censorship of sensitive material, thereby precluding their films from general cinematic release. The problems associated with the staging of film festivals in China to showcase queer documentaries have been well documented. ${ }^{48}$ Makers of queer documentaries and films have found it especially difficult to create a public platform for open viewing and discussion of their artwork without attracting attention (and intervention) from official channels.

Alternative offline tactics for distribution have relied upon reclassifying such screenings as private events or as film exchange weeks, in an attempt to avoid the political entanglements of using the word 'festival'. ${ }^{49}$ In major cities, films screenings are frequently held in bars catering to the tongzhi community.$^{50}$ Anecdotal evidence exists of queer film clubs operating within KTV clubs, cafés,${ }^{51}$ and gated apartment complexes, and even screenings held on moving vehicles.$^{52}$ Moreover, digitization (and China's ever-increasing internet penetration rate) enables tongzhi from all over China to access queerthemed film and documentaries through dedicated video streaming sites ${ }^{53} \mathrm{We}$ turn our attention to this new way of distributing and consuming queer documentaries in the following section.

\section{Viewing queer documentaries online: historical data analysis}

Online video hosting sites have become a popular way of sharing media content in China. With the major international streaming and social media platforms such as Youtube and Facebook blocked by China's Golden Shield project, the domestic market for sites delivering user-generated video content has flourished. Two of China's popular video content hosting sites are Youku (www.youku.com) and Tudou (www.tudou.com), which merged into one company in 2012, but still maintain separately branded channels. These two sites are ranked as $22^{\text {nd }}$ and $30^{\text {th }}$ respectively for Internet traffic volume within China (as of August 2016). Diagnostics provided by Alexa Web Information (www.alexa.com) suggests that Youku and Tudou users are primarily college-educated individuals aged 25 to 34 . International traffic to these sites comes primarily from the Asia-Pacific area and the USA. Like Sina Weibo, these sites attract a huge user base, and provide the potential for a great deal of exposure for uploaded material. Despite the restrictions on online content relating to the expression of sexuality, video clips, documentaries and short films on tongzhi life are easy to locate on these video hosting websites. Beneficially, accessing these websites does not carry any implications as to a user's sexual identity. This can be an important factor in allowing users to access content on shared computer facilities, who would otherwise be unwilling to access tongzhi lifestyle websites for fear of disclosing their sexuality to others.

\section{TAB01}

The Chinese tongzhi website Queer Comrades uploads video and documentary material to its own website, but Queer Comrades' films are also readily accessible via Youku accounts. Their 2012 documentary on homophobia and violence in China entitled Strong has received nearly 115,000 views (at 25 August 2012). In 2012, Youku provided data regarding a video's popularity, but this functionality has since been removed from the website. Today, comparable methods of data extraction exist through third-party software such as Google Analytics, which allows internet traffic referrals to be analysed in a similar manner. However, such software is intended for monitoring proprietary content, and therefore would require collaboration with the website owner for such software to be used effectively as a research tool. Therefore, we have been unable to replicate this data extraction on the documentary using this method. For comparison, YouTube provides a traffic sources report from within its own platform, yet this report too is only available to the video uploader. 
From the data in Table 1 above, we can see a referral traffic log (引用纪录), which records external websites containing direct links to this video. From this data, we can see that the video has been referenced 233 times by a Weibo user named LEStalk, and a further 160 times from Weibo user Lesparty. The quantity of these referrals will frequently arise from other users reblogging the original microblog post containing the link to this video from LEStalk and Lesparty's accounts, rather than the original poster referring the video numerous times. This data is significant, as it shows that video material such as this is being shared and forwarded through other websites, and in particular, through social networking sites. ${ }^{54}$ Reference to the popularity of the aforementioned video on the Youku platform was given in a microblog entry from $18^{\text {th }}$ July 2012 posted on the Queer Comrades Weibo account:

[Youku Homepage] Queer Comrades' documentary about campus violence "Strong" appeared on the main page of YOUKU documentary site [hyperlink] thanks to the director@weijiangang wufa daibiao xiao gang and the people being interviewed $[\ldots]^{55}$

\section{Youku.com: analysis of video referral traffic}

In order to test the hypothesis that social networking sites are promoting the viewing and distribution of tongzhi documentaries on media streaming sites, the historical Youku video diagnostics screens obtained in 2012 of ten randomly selected tongzhi documentaries (several of which were amateur productions) were analysed to investigate what types of website were referring viewers to the films. The websites were classified as:

- social networking sites (SNS), where subscribed users are able to share various types of media and information within their own networks.

- dedicated blog providers, which are freely accessible by the general public.

- microblogging platforms (for the purposes of this analysis, only sites which offer dedicated microblogging forums have been included). Registration is required to view posts.

- lifestyle websites with a specific focus on LGBTQ and/or tongzhi life and issues. Accessible without subscription/registration.

- General interest lifestyle websites, which do not specifically cater to LGBTQ and/or tongzhi audiences. Accessible without subscription/registration.

A summary of these results is provided below:

TAB02

From these figures, we derive the following information:

FIG05

Figure 5 illustrates the level of exposure that these ten documentary films have received during the period examined as a direct result of page referrals from other Internet sites. Contributing nearly $70 \%$ of referral traffic volume, social networking sites are clearly exerting the greatest influence. Microblogging and blogging sites have contributed nearly $20 \%$ of the exposure given to these videos. Only $11 \%$ of these videos have been directly linked by sites dedicated to LGBTQ and/or tongzhi interests, or from sites run by NGOs. This demonstrates the vital role played by social media sites on the Internet in increasing visibility of tongzhi documentaries, and shows how social media is helping to create an online public space for the consumption of non-fictional tongzhi programming.

The streaming of documentaries and films in Chinese cyberspace raises issues of copyright. On international video streaming sites, content is intended to be user-generated, or be reposted with the 
consent of the artist concerned. Frequently, video content is removed from such sites on the basis of copyright infringement, and forms a safeguard against loss of revenue for the individuals who have financed the production. However, China's video streaming site, whether through lack of legal recourse or through differing attitudes towards ownership of online content, do not routinely remove such items. For example, all 118 minutes of Cui Zi'en's landmark documentary on the history of the tongzhi rights movement in China is available on Youku, and the documentary has been accessible online for at least the last six years. ${ }^{56}$ The continued presence of such material raises again the question of artistic motivation. Allowing such work to be publicly accessible may serve as an indicator that such directors consider their roles as tongzhi rights activists to be more important than their roles as artists. When asked to give their primary goal and motivation for making documentary films, several directors and filmmakers have cited the need to increase visibility of tongzhi lives and issues within Chinese society. ${ }^{57}$ However, with increased exposure comes the increased likelihood of obstructive attention from official sources. Queer activists and artists alike must tread a fine line between promoting community visibility and transgressing governmental edict. In a digitally enabled community (even one which is subject to censorship) there is a huge potential for reaching out to marginalized individuals, and tongzhi activists in China have benefitted enormously from this new method of interconnectivity. Even as early as March of 2001, Time Magazine was claiming that the Internet had done as much in five years for Asia's gay community as the 25 years following Stonewall had done in the West. ${ }^{58}$

\section{Conclusion}

Inspired by the framework of circuit of culture in the examination of different yet inter-connected moments of queer documentary films, and employing inter-disciplinary approaches, this paper fills an important missing link in scholarly literature on how Chinese queer documentary filmmakers produce, promote and reach out to their audience in the increasingly digitized China. Our findings reveal that despite the restrictive internet culture in China, the public is much more exposed to queer online expression in the space carved out by the active queer filmmakers.

Countering early emancipatory claims of the Internet as a place where material realities of space and location are transcended, Lisa Nakamura demonstrates that the structural inequalities that exist in everyday life seamlessly feed over into digital realms. ${ }^{59}$ Increasingly, studies have continued to challenge the notion of the Internet as a democratizing or emancipatory tool, ${ }^{60}$ illustrating that the circular logic of this technological determinism bogs down academic analysis in an 'increasingly stale debate between digital activism and cyber-censorship. ${ }^{61}$ Mobile technologies are influencing nearly every facet of life, ${ }^{62}$ and it is clear that such technology has opened up alternative spaces for Queer expression and consumption, yet has this merely resulted in a marginalized offline population becoming marginalized online too? Has, therefore, the Internet becomes a platform of 'shallow infotainment, pernicious misinformation, and interest-based ghettos' ${ }^{63}$ For queer online expression, we argue that this is not the case. Owing to the media restrictions outlined in this paper, there are few offline spaces available for queer narratives and histories. Despite restrictions placed on freedom of speech within Chinese cyberspace, it is clear that the Internet provides an essential networking tool for China's diverse tongzhi community. Mobile technologies have been instrumental in increasing China's internet penetration rate,${ }^{64}$ changing the way in which people consume digital media. Consequently, Jason Farman states that mobile storytelling projects:

offer an intervention into the politics of site-specific storytelling by making visible the invisible stories, both those that are the common-sense grand narratives that function through their invisibility or those stories on the margins that have been made invisible by the dominant narratives of a place. ${ }^{65}$

Therefore, the claiming of portions of Chinese cyberspace represents an important breakthrough in public, visible queer expression. This is particularly vital in a country where frank and open discussion on sexuality is not commonplace. Increasingly, urban tongzhi are splitting their lives between a gay 
recreation-based world ${ }^{66}$ and the straight personal and professional persona that they are obliged to portray outside of the relative security of the tongzhi community. The Internet represents a vital form of connection for Chinese tongzhi. Groups associated with the advancement of tongzhi civil rights have embraced Internet technology to create a networked discourse platform, which enhances public visibility and works towards challenging public perception of sexual diversity. Makers of queer documentaries have recognized this, and have responded to the new opportunities that the Internet is providing.

Unlike in a global commercial environment, where media items are traded for profit, China's queer filmmakers have no public commercial platform upon which to exhibit their work. Advances in new media technology may enable an increasing number of netizens to view works (or snippets of them) via media streaming websites, but the artist does not receive payment for this, nor do they earn royalties. Therefore, it must be concluded that the artists who create these films do so not as a revenueearning vehicle, but rather as contributory pieces to a developing social movement.

As has been demonstrated, Chinese filmmakers have limited conventional channels to show their work to a domestic audience. However, examination of online video hosting websites suggests that social networking sites are being used to share domestically made documentaries on tongzhi topics within Chinese cyberspace. The short historical referral traffic study on online videos has indicated that in 2012, the majority of this traffic towards tongzhi documentaries was being directed from social network sites and microblogs. This analysis stands a novel contribution to the field, as it allows us to understand how different online spaces are interacting with the documentaries, and demonstrates how such channels of distribution are linked through cyberspace in ways which would not be possible to visualize through traditional cinematic distribution channels. Although conclusions drawn from such a smallscale study may not represent the overall trend, we can say that these early indications appear to demonstrate a positive trend in this regard.

Our microblog analysis has also revealed discussion of (and reference to) tongzhi documentary films. This indicates that, on some level, microblogging is contributing towards the promotion of both tongzhi documentaries and the artists who make them. The potential for exposure that comes from using a social networking site is practically limitless: Sina Weibo's registered users number in the hundreds of millions. Although the proportion of those users who are actively seeking queer resources is only a fraction of this number, the open nature of the platform, coupled with the comparative brevity of microblogging format, increases the likelihood of attracting new audiences and expanding cultural discourse on non-normative sexualities.

In sum, in their struggle for greater visibility and social acceptance, Chinese queer filmmakers have found a new platform in the new media technology and Web 2.0 to produce, promote and reaching out to the audience, thus evading some aspects of censorship. Their activism facilitated by the nature of the social media renders them great potential in contributing to the changing of the restrictive Internet culture.

\footnotetext{
${ }^{1}$ Margherita Viviani, Chinese independent documentary films: Alternative media, public spheres and the emergence of the citizen activist, Asian Studies Review 38(1), 2014: 107-23.

${ }^{2}$ Chris Berry, The documentary production process as a counter-public: Notes on an inter-Asian mode and the example of Kim Dong-Won, Inter-Asia Cultural Studies 4(1), 2003: 139.

${ }^{3}$ Ibid ., 140.

${ }^{4}$ See, for instance, Mandy Rose, Making publics: Documentary as do-it-with-others citizenship, in Matt Ratto and Megan Boler (eds) DIY Citizenship: Critical Making and Social Media, Cambridge Massachusetts: The
} 
MIT Press, 2014, 201-12; and Red Chidgey, (2014) Developing communities of resistance? Maker pedagogies, do-it-yourself feminism, and DIY citizenship, in Matt Ratto and Megan Boler (eds) DIY Citizenship: Critical Making and Social Media. Cambridge Massachusetts: The MIT Press, 2014, 101-14.

${ }^{5}$ See, for instance, Steffi Lau, Homosexuality in China USC US-China Institute, 3 October 2010,

http://www.uschina.usc.edu/w_usct/showarticle.aspx?articleID=14740, accessed 7 November 2010; Day Wong, Hybridization and the emergence of "gay" identities in Hong Kong and in China, Visual Anthropology 24(1-2), 2010:152-170; Timothy Hildebrandt, Development and division: The effect of transnational linkages and local politics on LGBT activism in China, Journal of Contemporary China 21(77), 2012: 845-862.

${ }^{6}$ Dongjin Yang, The status quo, causes, problems and countermeasures of China's film industry. Journal of Service Science and Management 08(06), 2015: 801-08.

7 电视剧内容管理规定 (TV content management regulations), 14 May 2010. http://www.gov.cn/flfg/201005/20/content_1609751.htm, accessed 16 August 2016.

${ }^{8}$ Mark McLelland, New media, censorship and gender: Using obscenity law to restrict online self-expression in Japan and China, in Larissa Hjorth and Olivia Khoo (eds) Routledge Handbook of New Media in Asia,

Albingdon and New York: Routledge, 2015, 118-29.

${ }^{9}$ Luke Robinson, Independent Chinese Documentary: From the Studio to the Street, London and New York: Palgrave Macmillan, 2013.

${ }^{10}$ Yiman Wang, The amateur's lightning rod: DV documentary in postsocialist China, Film Quarterly 58(4), 2005: 16-26.

${ }^{11}$ Chris Berry and Lisa Rofel, Introduction, in Chris Berry, Lisa Rofel and Xinyu Lu (eds) The New Chinese Documentary Film Movement: For the Public Record. Hong Kong: Hong Kong University Press, 2010, 3.

${ }^{12}$ Jia Tan, Aesthetics of queer becoming: Comrade Yue and Chinese community-based documentaries online, Critical Studies in Media Communication 33(1), 2016: 38-52.

${ }^{13}$ See, for instance, Chris Berry, Fran Martin and Audrey Yue, (2003) Introduction: Beep-click-link, in Chris Berry, Fran Martin and Audrey Yue (eds) Mobile Cultures: New Media in Queer Asia, Durham \& London: Duke University Press, 2003, 1-20; John E. Campbell, John E. (2004) Getting It On Online: Cyberspace, Gay Male Sexuality, and Embodied Identity, Birminghampton: Routledge, 2004; Imri Karl, On-/offline: Gender, sexuality and the techno-politics of everyday life, in Kate O'Riordan and David J. Phillips (eds) Queer Online: Media Technology \& Sexuality, New York: Peter Lang, 2007, 45-64; Ben Aslinger, PlanetOut and the dichotomies of queer media conglomeration, in Christopher Pullen and Margaret Cooper (eds) LGBT Identity and Online New Media, Albingdon and New York: Routledge, 2010, 113-24; Nikki Usher and Eleanor Morrison, Eleanor, The demise of the gay enclave, communication infrastructure theory, and the transformation of gay public space, in Christopher Pullen and Margaret Cooper (eds) LGBT Identity and Online New Media, Albingdon and New York: Routledge, 2010, 271-87.

${ }^{14}$ See, for instance, Elisabeth L. Engebretsen, William F. Schroeder and Hongwei Bao (eds) Queer/Tongzhi China: New Perspectives on Research, Activism and Media Cultures. Copenhagen: Nordic Institute of Asian Studies Press, 2015; Tan, Aesthetics of queer becoming, 38-52.

${ }^{15}$ The term tongzhi (originally meaning comrade) has become a popular term of reference for LGBT/Q (Lesbian, Gay, Bisexual, Transgender, and/or Queer) individuals in China.

${ }^{16}$ Paul Du Gay, Stuart Hall, Linda Janes, Anders K. Madsen, Hugh Mackay and Keith Negus Doing Cultural Studies: The Story of the Sony Walkman, London: Sage Publications, 1997.

${ }^{17}$ Wei's forename is rendered in English as Xiaogang (小刚), rather than Jiangang (建刚).

${ }^{18}$ Wah-shan Chou, Homosexuality and the Cultural Politics of Tongzhi in Chinese Societies. Journal of Homosexuality 40 (3-4), 2001: 27-46.

${ }^{19}$ See, for instance, Lokman Tsui, The panopticon as the antithesis of a space of freedom: Control and regulation of the Internet in China, China Information 17(2), 2003: 65-82; Yutian Ling, Upholding free speech and privacy online: A legal-based and market-based approach for Internet companies in China, Santa Clara Computer \& High Technology Law Journal 27(1), 2010: 175-217.

${ }^{20}$ Elisabeth L. Engebretsen, Queer ethnography in theory and practice: Reflections on studying sexual globalization and women's queer activism in Beijing. Graduate Journal of Social Science 5(2), 2008: 99.

${ }^{21}$ Loretta W.W. Ho Gay and Lesbian Subculture in Urban China. Oxford: Routledge, 2010.

${ }^{22}$ See, for instance, Thomas Lum, (2006) Internet development and information control in the People's Republic of China, Congressional Research Service, 10 February 2006.

https://www.fas.org/sgp/crs/row/RL33167.pdf, accessed 11 May 2011; Assafa Endeshaw, Internet regulation in China: The never- ending cat and mouse game, Information \& Communications Technology Law 13(1), 2009: 41-57.

23 电视剧通则曝光 早恋同性恋转世不得出现 (TV drama rules revealed: Puppy love, homosexuality, reincarnation must not be allowed to appear) 新浪娱乐 (Sina Entertainment), 2 February 2016. http://ent.sina.com.cn/v/m/2016-03-02/doc-ifxpvysv5119554.shtml, accessed 12 August 2016. 
${ }^{24}$ Xiaogang Wei 'Queer Comrades' and Online Queer Media Production (paper presented at 'Visuality and Politics: Queer Media in China' workshop at Nottingham Trent University, 26 March 2012).

${ }^{25}$ Recorded in an interview for this project, conducted in July 2012.

${ }^{26}$ Zhang, Yingjin, My camera doesn't lie? Truth, subjectivity, and audience in Chinese independent film and video, in Paul G. Pickowicz and Yingjin Zhang (eds) From Underground to Independent: Alternative Film Culture in Contemporary China, Oxford: Rowman \& Littlefield, 2006, 23-46.

${ }^{27}$ See, for instance, Berry and Rofel, Introduction, 3-14; Tan, Aesthetics of queer becoming, 38-52; Wenguang Wu, DV: Individual filmmaking, in Chris Berry, Lisa Rofel and Xinyu Lu (eds) The New Chinese Documentary Film Movement: For the Public Record. Hong Kong: Hong Kong University Press, 2010, 49-54.

${ }^{28}$ Marshall McLuhan and Barrington Nevitt, Barrington, Take Today: The Executive as Drop-Out, New York: Harcourt Brace Jovanovich, 1972.

${ }^{29}$ See, for instance, Zi'en Cui, The communist international of queer film. Positions: East Asia Cultures Critique 18(2), 2010: 417-23; Popo Fan, Interview with Cui Zi'en, in Elisabeth L. Engebretsen, William F. Schroeder and Hongwei Bao (eds) Queer/Tongzhi China: New Perspectives on Research, Activism and Media Cultures. Copenhagen: Nordic Institute of Asian Studies Press, 2015, 245-66; Deklerck, Stijn. and Wei, Xiaogang, Queer online media and the building of China's LGBT community, in Elisabeth L. Engebretsen, William F. Schroeder and Hongwei Bao (eds) Queer/Tongzhi China: New Perspectives on Research, Activism and Media Cultures. Copenhagen: Nordic Institute of Asian Studies Press, 2015, 18-34.

${ }^{30}$ Deklerck and Wei, Queer online media and the building of China's LGBT community, 18-34.

${ }^{31}$ Ibid.

${ }^{32}$ Leach, Anna (2012) Welcome to Gay China TV Gaystar News, 8 June 2012.

http://www.gaystarnews.com/article/welcome-gay-china-tv080612, accessed 14 August 2012.

${ }^{33}$ The 37th statistical report on internet development in China, CNNIC, January 2016,

https://www1.cnnic.cn/IDR/ReportDownloads/201604/P020160419390562421055.pdf, accessed 12 May 2016. ${ }^{34}$ Ibid.

${ }^{35}$ China's infrastructure leap. The Economist Intelligence Unit, 12 February 2016,

http://www.eiu.com/industry/article/1573938941/chinas-infrastructure-leap/2016-02-24, accessed 11 August 2016

${ }^{36}$ The 37th statistical report on internet development in China, CNNIC

${ }^{37}$ Patrick Frater, Youku Todou executive Victor Koo discusses streaming company's future, Variety, 5

September 2014, http://variety.com/2014/digital/global/youku-tudou-executive-victor-koo-interview-

1201296375/, accessed 11 August 2016.

${ }^{38}$ Berry and Rofel, Introduction, 3-14.

${ }^{39}$ See, for instance, Adrian Palmer and Nicole Koenig-Lewis, An experiential, social network-based approach to direct marketing, Direct Marketing: An International Journal 3(3), 2009: 162-76; Anthony Patino, Dennis Pitta and Ralph Quinones, Social media's emerging importance in market research, Journal of Consumer Marketing 29(3), 2012: 233-37.

${ }^{40}$ Where microblog contains @ username anywhere in the body of the text, the content will appear on the page of the original poster and any other listed users.

${ }^{41}$ Zi’en Cui (崔子恩), 誌同志 (Queer China, 'Comrade' China) [Film], dGenerate Films, 2008.

${ }^{42}$ Popo Fan, recorded in an interview for this project, conducted in July 2012

${ }^{43}$ As noted by Ho, Gay and Lesbian Subculture in Urban China.

${ }^{44}$ Austin Ramzy, 2011. Wired Up, Time, 17 February 2011.

http://www.time.com/time/printout/0,8816,2048171,00.html, accessed 29 May 2016.

${ }^{45}$ The term harmonized 和谐 has become Internet slang for censored.

46 计算机信息网络国际联网安全保护管理办法（公安部令第 33 号） (Computer information network and internet security, protection and management [Ministry of Public Security order no. 33]), 中华人民共和国中央 人民政府 (The State Council of the People's Republic of China), 16 December 1997,

http://www.gov.cn/gongbao/content/2011/content_1860856.htm, accessed 02 February 2017.

${ }^{47}$ Quoted in Kathy Chu and Calum MacLeod, Gay life in China is legal, but remains hidden, USA Today, 21 February 2010. http://www.usatoday.com/news/world/2010-02-21-gays-China-closeted_N.htm, accessed 3 August 2012.

${ }^{48}$ See, for instance, Chris Berry, Lisa Rofel and Xinyu Lu (eds) The New Chinese Documentary Film Movement: For the Public Record. Hong Kong: Hong Kong University Press, 2010; Cui, The communist international of queer film; Travis S.K. Kong, (2011) Chinese Male Homosexualities; Memba, Tongzhi and Golden Boy, Oxford: Routledge, 2011; Rex Wockner, Beijing Queer Film Festival goes guerrilla, Pridesource, 30 June 2011, http://www.pridesource.com/article.html?article=47827, accessed 12 August 2016; Cindy HingYuk Wong, Film Festivals Culture, People, and Power on the Global Screen. New Brunswick: Rutgers University Press, 2010; China: Country Summary, Human Rights Watch, January 2010, http://www.hrw.org/sites/default/files/related_material/china_2012_0.pdf, accessed 15 August 2012. 
${ }^{49}$ See, for instance, Berry et al (eds) The New Chinese Documentary Film Movement; Hongwei Bao, Digital video activism, in Elisabeth L. Engebretsen, William F. Schroeder and Hongwei Bao (eds) Queer/Tongzhi China: New Perspectives on Research, Activism and Media Cultures. Copenhagen: Nordic Institute of Asian Studies Press, 2015, 35-56.

${ }^{50}$ See, for instance, Elisabeth L. Engebretsen, Queer Women in Urban China: An Ethnography. New York: Routledge, 2014; Beijing: bars, cabarets, clubs, discos \& karaoke, Utopia, http://www.utopiaasia.com/beijbars.htm, accessed 25 February 2017.

${ }^{51}$ Asako Fujioka, Documentaries south of the clouds, Yamagata International Documentary Film Festival, 10 May 2004, http://www.yidff.jp/docbox/23/box23-3-e.html, accessed 4 April 2017.

${ }^{52}$ See, for instance, Hongwei Bao, Queer filmmaking in the People's Republic of China, CPI Analysis, 22 August 2016. https://cpianalysis.org/2016/08/22/queer-filmmaking-in-the-peoples-republic-of-china/, accessed 21 February 2017; Qin Qin, Queer Film in China: Predicaments, Politics and Progress. The International Academic Forum, 2 May 2016, http://think.iafor.org/queer-film-china-predicaments-politics-progress/, accessed 2 February 2017.

${ }^{53}$ Elaine Jeffreys and Haiqing Yu, Sex in China. Cambridge: Polity Press, 2015.

${ }^{54}$ Douban 豆瓣 (www.douban.com), which is the top-rated site featured in figure 5, is a Chinese social networking site which allows registered users to record information and create content related to film, books, music, and recent events and activities in Chinese cities 55 同志亦凡人一部纪录校园暴力的短片《你如此坚强》登上优酷纪录片首页 (Queer Comrades' documentary about campus violence 'Strong' appeared on the main page of Youku documentary site) 新郎微博 (Sina Microblog), 18 July 2012, http://www.weibo.com/1286173051/yt159oTAf, accessed 20 August 2012. ${ }^{56}$ Based on the authors' observation, having viewed the documentary several times online since 2010.

${ }^{57}$ See, for instance, Dinah Gardner, Woman on film, Fridae, 23 January 2007, http://www.fridae.asia/gaynews/2007/01/23/1776.woman-on-film?n=sec, accessed 4 April 2017; Cui (崔子恩), 誌同志 (Queer China, 'Comrade' China); Queer Comrades, China LGBT community leader conference debates the future of the Chinese LGBT movement, Queer Comrades, 17 June 2012, http://www.queercomrades.com/en/blog/china-lgbtconference/, accessed 20 August 2012.

${ }^{58}$ Berry et al, Introduction, 1-20. The Stonewall Riots, which took place in New York in 1969, are generally credited with marking the start of the gay rights movement in Western society.

${ }^{59}$ Lisa Nakamura, Cyberrace. PMLA 123(5), 2008: 1673-82.

${ }^{60}$ See, for instance, Matthew S. Hindman, The Myth of Digital Democracy, Princeton: Princeton University Press, 2009; James Leibold, Blogging alone: China, the Internet, and the democratic illusion? The Journal of Asian Studies 70(4), 2011: 1023-41.

${ }^{61}$ Leibold, Blogging Alone: 1023.

${ }^{62}$ Jason Farman, Stories, spaces, and bodies: The production of embodied space through mobile media storytelling, Communication Research and Practice 1(2), 2015: 101-16.

${ }^{63}$ Leibold, Blogging Alone: 1025.

${ }^{64}$ The 37th statistical report on internet development in China, CNNIC.

${ }^{65}$ Farman, Stories, spaces, and bodies: 110.

${ }^{66}$ William F. Schroeder, Beyond resistance: Gay and lala recreation in Beijing, in Peter Aggleton, Paul Boyce, Henrietta L. Moore and Richard Parker (eds), Understanding Global Sexualities: New Frontiers, New York: Routledge, 2012, 108-23.

\section{References}

Aslinger, Ben (2010) PlanetOut and the dichotomies of queer media conglomeration. In: Pullen, Christopher and Cooper, Margaret (eds) LGBT Identity and Online New Media. Albingdon and New York: Routledge, $113-24$

Bao, Hongwei (2016) Queer filmmaking in the People's Republic of China. CPI Analysis, 22 August. https://cpianalysis.org/2016/08/22/queer-filmmaking-in-the-peoples-republic-of-china/, accessed 4 April 2017. 
Bao, Hongwei (2015) Digital video activism. In: Engebretsen, Elisabeth L., Schroeder, William F., and Bao, Hongwei (eds) Queer/Tongzhi China: New Perspectives on Research, Activism and Media Cultures. Copenhagen: Nordic Institute of Asian Studies Press, 35-56.

Berry, Chris (2003) The documentary production process as a counter-public: notes on an inter-Asian mode and the example of Kim Dong-Won. Inter-Asia Cultural Studies 4(1): 139-44.

Berry, Chris, Martin, Fran, and Yue, Audrey (2003) Introduction: Beep-click-link. In: Berry, Chris, Martin, Fran, and Yue, Audrey (eds) Mobile Cultures: New Media in Queer Asia. Durham \& London: Duke University Press, 1-20.

Berry, Chris and Rofel, Lisa (2010) Introduction. In: Berry, Chris, Rofel, Lisa, and Lu, Xinyu (eds) The New Chinese Documentary Film Movement: For the Public Record. Hong Kong: Hong Kong University Press, 3-14.

Berry, Chris, Rofel, Lisa, and Lu, Xinyu (eds) (2010) The New Chinese Documentary Film Movement: For the Public Record. Hong Kong: Hong Kong University Press.

Campbell, John E. (2004) Getting It On Online: Cyberspace, Gay Male Sexuality, and Embodied Identity. Birminghampton: Routledge.

Chidgey, Red (2014) Developing communities of resistance? Maker pedagogies, do-it-yourself feminism, and DIY citizenship. In: Ratto, Matt and Boler, Megan (eds) DIY Citizenship: Critical Making and Social Media. Cambridge Massachusetts: The MIT Press, 101-14.

Chou, Wah-shan (2001) Homosexuality and the Cultural Politics of Tongzhi in Chinese Societies. Journal of Homosexuality 40(3-4): 27-46.

Chu, Kathy and MacLeod, Calum (2010) Gay life in China is legal, but remains hidden USA Today, 21 February. http://www.usatoday.com/news/world/2010-02-21-gays-China-closeted_N.htm, accessed 4 April 2017.

The 37th statistical report on internet development in China (2016) CNNIC, January. https://cnnic.com.cn/IDR/ReportDownloads/201604/P020160419390562421055.pdf, accessed 4 April 2017.

Annual Report 2011 (2011) Congressional-Executive Commission on China, 15 August. http://www.cecc.gov/publications/annual-reports/2011-annual-report, accessed 4 April 2017.

Cui, Zi'en (2010) The communist international of queer film. Positions: East Asia Cultures Critique 18(2): 417-23.

Cui, Zi’en 催子恩 (2008) 誌同志 (Queer China, ‘Comrade’ China). dGenerate Films.

Deklerck, Stijn and Wei, Xiaogang (2015) Queer online media and the building of China's LGBT community. In: Engebretsen, Elisabeth L., Schroeder, William F., and Bao, Hongwei (eds) Queer/Tongzhi China: New Perspectives on Research, Activism and Media Cultures. Copenhagen: Nordic Institute of Asian Studies Press, 18-34.

Du Gay, Paul, Hall, Stuart, Janes, Linda, Madsen, Anders K., Mackay, Hugh, and Negus, Keith (1997) Doing Cultural Studies: The Story of the Sony Walkman. London: Sage Publications.

Endeshaw, Assafa (2009) Internet regulation in China: The never- ending cat and mouse game. Information \& Communications Technology Law 13(1): 41-57.

Engebretsen, Elisabeth L. (2014) Queer Women in Urban China: An Ethnography. New York: Routledge.

Engebretsen, Elisabeth L. (2008) Queer ethnography in theory and practice: Reflections on studying sexual globalization and women's queer activism in Beijing. Graduate Journal of Social Science 5(2): 88-116. 
Engebretsen, Elisabeth L., Schroeder, William F., and Bao, Hongwei (eds) (2015) Queer/Tongzhi China: New Perspectives on Research, Activism and Media Cultures. Copenhagen: Nordic Institute of Asian Studies Press.

Fan, Popo (2015) Interview with Cui Zi'en. In: Engebretsen, Elisabeth L., Schroeder, William F., and Bao, Hongwei (eds) Queer/Tongzhi China: New Perspectives on Research, Activism and Media Cultures. Copenhagen: Nordic Institute of Asian Studies Press, 245-66.

Farman, Jason (2015) Stories, spaces, and bodies: The production of embodied space through mobile media storytelling. Communication Research and Practice 1(2): 101-16.

Frater, Patrick (2014) Youku Todou executive Victor Koo discusses streaming company’s future. Variety, 5 September. http://variety.com/2014/digital/global/youku-tudou-executive-victor-koo-interview1201296375/, accessed 4 April 2017.

Fujioka, Asako (2004) Documentaries south of the clouds. Yamagata International Documentary Film Festival, 10 May. http://www.yidff.jp/docbox/23/box23-3-e.html, accessed 4 April 2017.

Gardner, Dinah (2007) Woman on film. Fridae, 23 January. http://www.fridae.asia/gaynews/2007/01/23/1776.woman-on-film?n=sec, accessed 4 April 2017.

Hildebrandt, Timothy (2012) Development and division: The effect of transnational linkages and local politics on LGBT activism in China. Journal of Contemporary China 21(77): 845-862.

Hindman, Matthew S. (2009) The Myth of Digital Democracy. Princeton: Princeton University Press

Ho, Loretta W.W. (2010) Gay and Lesbian Subculture in Urban China. Oxford: Routledge

China: Country Summary (2012) Human Rights Watch, January. http://www.hrw.org/sites/default/files/related_material/china_2012_0.pdf, accessed 4 April 2017.

Jeffreys, Elaine and Yu, Haiqing (2015) Sex in China. Cambridge: Polity Press.

Karl, Irmi (2007) On-/offline: Gender, sexuality and the techno-politics of everyday life. In: O'Riordan, Kate and Phillips, David J. (eds) Queer Online: Media Technology \& Sexuality. New York: Peter Lang, 45-64.

Kong, Travis S.K. (2011) Chinese Male Homosexualities; Memba, Tongzhi and Golden Boy. Oxford: Routledge.

Lagerkvist, Johan (2005) The techno-cadre's dream: Administrative reform by electronic governance in China today? China Information 19(2): 189-216.

Lau, Steffi (2010) Homosexuality in China USC US-China Institute, 3 October. http://www.uschina.usc.edu/w_usct/showarticle.aspx?articleID=14740, accessed 4 April 2017.

Leach, Anna (2012) Welcome to Gay China TV Gaystar News, 8 June. http://www.gaystarnews.com/article/welcome-gay-china-tv080612, accessed 4 April 2017.

Leibold, James (2011) Blogging alone: China, the Internet, and the democratic illusion? The Journal of Asian Studies 70(4): 1023-41.

Ling, Yutian (2010) Upholding free speech and privacy online: A legal-based and market-based approach for Internet companies in China. Santa Clara Computer \& High Technology Law Journal 27(1): 175-217.

Lum, Thomas (2006) Internet development and information control in the People's Republic of China Congressional Research Service, 10 February. https://www.fas.org/sgp/crs/row/RL33167.pdf, accessed 4 April 2017. 
McLelland, Mark (2015) New media, censorship and gender: Using obscenity law to restrict online selfexpression in Japan and China. In: Hjorth, Larissa and Khoo, Olivia (eds) Routledge Handbook of New Media in Asia. Albingdon and New York: Routledge, 118-29.

McLuhan, Marshall and Nevitt, Barrington (1972) Take Today: The Executive as Drop-Out. New York: Harcourt Brace Jovanovich.

计算机信息网络国际联网安全保护管理办法 (Computer information network and internet security, protection and management) (1997) 中华人民共和国中央人民政府 (The State Council of the People’s Republic of China), 16 December. http://www.gov.cn/gongbao/content/2011/content_1860856.htm, accessed 4 April 2017.

Nakamura, Lisa (2008) Cyberrace. PMLA 123(5): 1673-82.

Palmer, Adrian and Koenig-Lewis, Nicole (2009) An experiential, social network-based approach to direct marketing. Direct Marketing: An International Journal 3(3): 162-76.

Patino, Anthony, Pitta, Dennis, and Quinones, Ralph (2012) Social media's emerging importance in market research. Journal of Consumer Marketing 29 (3): 233-37.

中国公民依法享有互联网上充分的言论自由 (Chinese citizens are legally entitled to full freedom of expression on the Internet) (2010) 人民网 (People’s Daily Online), 8 June. http://politics.people.com.cn/GB/1026/11813926.html, accessed 4 April 2017.

Qin, Qin (2016) Queer film in China: Predicaments, politics and progress. The International Academic Forum, 2 May. http://think.iafor.org/queer-film-china-predicaments-politics-progress/, accessed 4 April 2017.

同志亦凡人一部纪录校园暴力的短片 《你如此坚强》登上优酷纪录片首页(Queer Comrades' Documentary about Campus Violence 'Strong' Appeared on the Main Page of Youku Documentary Site) (2012) 新郎 微博 (Sina Microblog), 18 July. http://www.weibo.com/1286173051/yt159oTAf, accessed 4 April 2017.

China LGBT community leader conference debates the future of the Chinese LGBT movement (2012) Queer Comrades, 17 June. http://www.queercomrades.com/en/blog/china-lgbt-conference/, accessed 4 April 2017.

Ramzy, Austin (2011) Wired up. Time, 17 February. http://www.time.com/time/printout/0,8816,2048171,00.html, accessed 4 April 2017.

Robinson, Luke (2013) Independent Chinese Documentary: From the Studio to the Street. London and New York: Palgrave Macmillan.

Rose, Mandy (2014) Making publics: Documentary as do-it-with-others citizenship. In: Ratto, Matt and Boler, Megan (eds) DIY Citizenship: Critical Making and Social Media. Cambridge Massachusetts: The MIT Press, 201-12.

Schroeder, William F. (2012) Beyond resistance: Gay and lala recreation in Beijing. In: Aggleton, Peter, Boyce, Paul, Moore, Henrietta L., and Parker, Richard (eds) Understanding Global Sexualities: New Frontiers. New York: Routledge, 108-23.

电视剧通则曝光 早恋同性恋转世不得出现 (TV drama rules revealed: Puppy love, homosexuality, reincarnation must not be allowed to appear) (2016) 新浪娱乐 (Sina Entertainment), 2 February 2016. http://ent.sina.com.cn/v/m/2016-03-02/doc-ifxpvysv5119554.shtml, accessed 4 April 2017.

电视剧内容管理规定 (TV content management regulations) (2010) 中华人民共和国中央人民政府 (The State Council of the People's Republic of China), 14 May. http://www.gov.cn/flfg/201005/20/content_1609751.htm, accessed 4 April 2017. 
Tan, Jia (2016) Aesthetics of queer becoming: Comrade Yue and Chinese community-based documentaries online. Critical Studies in Media Communication 33(1): 38-52.

Tan, Jia (2010) Beyond visibility: Independent Chinese queer videos in the era of transnationalism. Cultural Studies Monthly (103).

China's infrastructure leap (2016) The Economist Intelligence Unit, 12 February. http://www.eiu.com/industry/article/1573938941/chinas-infrastructure-leap/2016-02-24, accessed 4 April 2017.

Tsui, Lokman (2003) The panopticon as the antithesis of a space of freedom: Control and regulation of the Internet in China. China Information 17(2): 65-82.

Usher, Nikki and Morrison, Eleanor (2010) The demise of the gay enclave, communication infrastructure theory, and the transformation of gay public space. In: Pullen, Christopher and Cooper, Margaret (eds) LGBT Identity and Online New Media. Albingdon and New York: Routledge, 271-87.

Utopia (2017) Beijing: bars, cabarets, clubs, discos \& karaoke. Utopia, n.d. http://www.utopiaasia.com/beijbars.htm, accessed 4 April 2017.

Viviani, Margherita (2014) Chinese independent documentary films: Alternative media, public spheres and the emergence of the citizen activist. Asian Studies Review 38(1): 107-23.

Wang, Yiman (2005) The amateur's lightning rod: DV documentary in postsocialist China. Film Quarterly 58(4): 16-26.

Wei, Xiaogang (2012) 'Queer Comrades' and Online Queer Media Production. Paper presented at 'Visuality and Politics: Queer Media in China’ conference at Nottingham Trent University, 26 March 2012.

Wockner, Rex (2011) Beijing Queer Film Festival goes guerrilla. Pridesource, 30 June. http://www.pridesource.com/article.html?article=47827, accessed 4 April 2017.

Wong, Cindy Hing-Yuk (2011) Film Festivals Culture, People, and Power on the Global Screen. New Brunswick, N.J.: Rutgers University Press.

Wong, Day (2010) Hybridization and the emergence of "gay" identities in Hong Kong and in China. Visual Anthropology 24(1-2): 152-170.

Wu, Wenguang (2010) DV: individual filmmaking. In: Berry, Chris, Rofel, Lisa, and Lu, Xinyu (eds) The New Chinese Documentary Film Movement: For the Public Record. Hong Kong: Hong Kong University Press, 49-54.

Yang, Dongjin (2015) The status quo, causes, problems and countermeasures of China's film industry. Journal of Service Science and Management 08(06): 801-08.

Zhang, Yingjin (2006) My camera doesn't lie? Truth, subjectivity, and audience in Chinese independent film and video. In: Paul G. Pickowicz and Yingjin Zhang (eds) From Underground to Independent: Alternative Film Culture in Contemporary China. Oxford: Rowman \& Littlefield, 23-46. 